\title{
Does collaborative divorce have a place in South African divorce law?
}

\author{
Motseotsile Clement Marumoagae \\ LLM, LLM AIPSA Dip Insolvency \\ Senior Lecturer, School of Law, University of the Witwatersrand
}

\begin{abstract}
OPSOMMING
Het gesamentlike wet 'n plek in die Suid-Afrikaanse egskeidingsreg?

Hierdie artikel bestudeer samewerkende beslegting as 'n alternatiewe geskils beslegtingsmetode in egskeidingsaangeleenthede. Dit bespreek verder die ontwikkeling, sowel as die kenmerke van kollektiewe reg. Verder sal melding gemaak word van hoe samewerkende bedinging van ander beslegtingsmetodes verksil. Hierdie artikel evalueer beide die vooren nadele van samewerkende beslegting in egskeidingsake en hoe dit in die Verenigde State van Amerika ontwikkel het. In hierdie artikel word 'n saak gemaak vir die wyer aanwending van hierdie metode in egskeidingsake in Suid-Afrika deur family prokureurs.
\end{abstract}

\section{Introduction}

Academics, lawyers, courts and legislatures have shown support for alternatives to litigation based resolution of family disputes. ${ }^{1}$ Alternative dispute resolution methods aim to create suitable atmosphere for parties to attempt to resolve their disputes by adopting processes that would allow them to engage meaningfully with each other. Recently, there have been unprecedented efforts to develop strategies aimed at more efficient, less costly and more satisfying resolution of family conflicts, including more extensive and appropriate use of various alternative dispute resolution approaches. ${ }^{2}$

A variety of innovative methods have been introduced to family law practice to minimise the harmful effects of an adversary system. Collaborative law is one of the alternative dispute resolution mechanisms which have been used by family law practitioners over the years to resolve family law disputes. Collaborative law has neither been practiced formally nor endorsed in South Africa despite clear evidence of its

1 Teitelbaum \& Du Paix 'Alternative Dispute Resolution and Divorce: Natural Experimentation in Family Law' 1988 Rutgers Law Review 1132. See also the Children's Act 38 of 2005, MB v NB 2010 (3) SA 220 (GSJ) and Boniface 'A humanistic approach to divorce and family mediation in the South African context: A comparative study of Western-style mediation and African humanistic mediation' 2012 African Journal on Conflict Resolution 101-129.

2 Stipanowich "ADR and the "Vanishing Trial": The Growth and Impact of "Alternative Dispute Resolution"' 2004 Journal of Empirical Legal Studies 843.

How to cite: Marumoagae 'Does collaborative divorce have a place in South African divorce law?' 2016 De Jure 41-57

http://dx.doi.org/10.17159/2225-7160/2016/v49n1a3 
effectiveness in foreign jurisdictions like the United States of America. ${ }^{3}$ In South Africa, mediation has been advocated as somewhat suitable alternative method of resolution of disputes in family law matters generally and divorce cases in particular. ${ }^{4}$ The purpose of this paper is to provide a contextual understanding of what collaborative law in the context of divorces is, with a view to assess whether it can be successfully practiced in South Africa. This will be done, first, by tracing the history of collaborative law. The article will then critically discuss the advantages and disadvantages of collaborative law with a view to determine whether collaborative law has a role to play in South African family law.

\section{Historical Perspective}

An American family law attorney, Stu Webb, is credited for having started the collaborative law movement in the United States of America ('USA'). 5 This practice was the result of Webb's unhappiness and bitterness towards the traditional adversarial nature of family law litigation. ${ }^{6}$ Webb defines collaborative law as 'a method of practising law in which attorneys assist their clients in resolving conflict and making agreements using cooperative strategies rather than litigation'. 7 Webb rejected the confrontational and adversarial nature of his practice and approached fellow family law practitioners within the area his practice

3 See Voegele, Wray \& Ousky 'Collaborative law: A useful tool for the family law practitioner to promote better outcomes' 2007 William Mitchell Law Review 971, where it is observed that 'a collaborative case may seem simple on its face. Yet, the art of the practice has a deep theoretical framework and dynamics. As a result, the dispute resolution model provides the potential for professional challenge and a higher degree of satisfaction for the attorney in helping the client through the challenges of a divorce'.

$4 \quad M B v N B$ supra $n$ 1; see also $S$ v J (695/10) [2010] ZASCA 139 (2010-11-19) par 54 where Lewis JA endorsed 'the views expressed by Brassey AJ in $M B v$ $N B$ that mediation in family matters is a useful way of avoiding protracted and expensive legal battles, and that litigation should not necessarily be a first resort'.

5 See Voegele, Wray \& Ousky supra $n 3$ at 974; see also Webb 'An Idea whose Time has Come: Collaborative Law an alternative for attorneys suffering from "family burnout"' 2000 Matrimonial Strategies 7.

6 See Webb 'Collaborative Law: A practitioner's perspective on its history and current practice' 2008 Journal of the American Academy of Matrimonial Lawyers 156, where the author provides his account of how this movement started by stating that 'in the late 1980s, after practicing traditional civil law for eight years and family law for additional seventeen years, I was approaching burn-out. I had to come to hate the adversarial nature of my practice and hated to go to work. It was becoming harder and harder to tolerate my family practice. I was prepared to stop practising law. ... So then I started thinking: Rather than stop practicing law, maybe I could continue my family law practice by developing a model that would allow me to do the parts of my practice which I enjoy and eliminate the parts I did not like. I felt like there had to be a better way to help people resolve their divorcing issues. I developed the insight that lawyers needed to be working with and representing clients for settlement'. Idem 155. 
was based, and sold them an idea of settling family law disputes through non-adversarial collaborative efforts. ${ }^{8}$ Webb decided to stop litigating and going to court and resolved to represent his clients only in negotiations which were aimed exclusively at settlement. ${ }^{9}$ However, where negotiations broke down and a settlement could not be reached, opening up the window for litigation, Webb withdrew and advised his client to obtain another legal representative who would litigate on their behalf. ${ }^{10}$

Webb believed that collaborative law was the way in which law should be practiced and thus, together with some of his colleagues, formed the Collaborative Law Institute of Minnesota - a non-profit organisation which has been used as a vehicle to spread the collaborative law doctrine. ${ }^{11}$ Webb also provided training to law practitioners who were interested in practising collaborative law. Since 1993, collaborative law has spread throughout the USA and Canada and it has also been introduced in the United Kingdom of Great Britain ('United Kingdom'). ${ }^{12}$ Collaborative law has received wide spread support both in the USA and Canada, which has led to the training of many collaborative lawyers who later became instrumental in the resolution of family law cases, particularly divorces. ${ }^{13}$ Currently, Collaborative law is practiced in virtually every state and province in the USA and Canada, as well in the United Kingdom and Australia. ${ }^{14}$ The continued growth of Collaborative Law has also sparked the interest and curiosity of not only the academic community and law regulatory bodies but also courts and legislators in the USA. Some of the USA's states have enacted statutes of varying length and complexity that recognise collaborative law. ${ }^{15}$

8 Fairman 'A Proposed Model Rule for Collaborative Law' 2005 Ohio State Journal on Dispute Resolution 78.

9 Schwab 'Collaborative Lawyering: A Closer Look at an Emerging Practice' 2004 Pepperdine Dispute Resolution Law Journal 354.

10 Idem 355.

11 CLIM 'We are happy you are thinking about joining the Collaborative Law Institute!' available from http://www.collaborativelaw.org/ (accessed 201411-14).

12 Fairman supra $\mathrm{n} 8$ at 83. See also Foran 'Adoption of the Uniform Collaborative Law Act in Oregon: The Right Time and the Right Reasons' 2009 Lewis and Klerk Law Review 789.

13 Fairman 'Growing Pains: Changes in Collaborative Law and the Challenge of Legal Ethics' 2008 Campbell Law Review 239.

14 Tesler 'Collaborative Family Law' 2004 Pepperdine Dispute Resolution Law Journal 318, wherein she observes that 'by the late 1990's, vigorous communities of collaborative practitioners had formed and begun representing family law clients in California, New Mexico, Arizona, Florida, Georgia, Pennsylvania, New York, Connecticut, Massachusetts, New Hampshire, Ohio, Illinois, Minnesota, Wisconsin, Colorado, Utah, British Columbia, Alberta, and Ontario. Today, the model has expanded to Ireland and the United Kingdom, Austria and Australia'.

15 See art 4 of the North Carolina General Statutes, Collaborative Family Law Act 2014 (New Jersey), California Family Code 2013 (2007) and Uniform Collaborative Law Act 2011 (Texas). See also Fairman supra n 13 at 340. 


\section{Collaborative Law in Family Matters}

Collaborative law can be understood as a voluntary mechanism which divorcing parties, together with their respective legal representatives, decide to utilise in order to resolve disputes between them, thus creating an environment for the parties to find an amicable solution to their disputes. According to Peppet:

In Collaborative Law, both divorcing parties agree to hire self-identified "collaborative lawyers" to handle their case. The lawyers and parties then agree that, so long as a so-called collaborative lawyer represents each side, the attorneys will serve their clients only during negotiations. In other words, if the attorneys fail to settle the case, they will withdraw. The parties and their lawyers sign "limited retention" agreements (LRAs) that limit the scope of the lawyer-client relationships and require the lawyers to withdraw if they cannot reach settlement. These agreements explain the lawyer's limited role and the mandatory mutual withdrawal provisions. In addition, the parties and their lawyers sign a "collaborative law participation" agreement (CLPA) at the start of their negotiations. This is a contract with the other side that signifies mutual interest in the Collaborative Law process. ${ }^{16}$

At the start of the collaborative law process, the parties, together with their legal representatives, bind themselves to engage in interest-based rather than positional bargaining, in order to jointly deal with issues which emanate from their disputes. ${ }^{17}$ The deliberate avoidance of positional bargaining allows parties to be more open minded when negotiating, and thus allows them to consider each other's interests and those of their children (if they have any). Such an approach allows parties to adequately understand each other's needs and not to be unreasonable when negotiating for individual interests. Depending on the financial wellbeing of the parties, over and above their respective legal representatives, they can also hire one or more experts depending on their needs. For instance, they can hire a child development specialist, accountant, or a real estate appraiser to advise them fully with regard to their children, finances or properties. In order to ensure a certain level of fairness, experts who are brought in to assist parties to reach an amicable resolution - and thus be in a position to settle - need to be partial and neutral. However, should they fail to assist the parties as expected and the matter ends up in court, then they would be disqualified from testifying in court. ${ }^{18}$

16 Peppet 'Lawyers' bargaining ethics, contract, and collaboration: The end of the legal profession and the beginning of professional pluralism' 2005 Iowa Law Review 488.

17 Difonzo 'From Dispute Resolution to Peacemaking: A Review of Collaborative Divorce Handbook? Helping Families without Going to Court by Forrest S. Mosten' 2010 Family Law Quarterly 99.

18 Tesler Collaborative Law: Achieving Effective Resolution in Divorce without Litigation (2001) 106. 
There have been a variety of definitions and models of collaborative law which have been put forward. ${ }^{19}$ However, collaborative law is generally premised on what proponents argue is a fundamental paradigm shift in the lawyer's role: An overriding commitment to settlement of a dispute outside the traditional litigation model combined with individualised legal advocacy within a collaborative environment'.20 It is meant to make legal representatives true counsellors to their clients by developing and utilising unique problem solving skills designed and aimed at reaching the best available outcome for both parties for the post-divorce restructured family, especially when children are involved. It also creates an environment wherein 'clients are supported by their legal representatives to aim for reasonable, mutually-respectful agreements as the normal, expected way to resolve divorce related disputes, and are taught to regard litigation as the "emergency room cum intensive care unit" of the legal system'. ${ }^{21}$

Collaborative law is founded on both parties and their respective legal representatives entering into a written agreement wherein all the parties to the process commit themselves to respectful and good faith negotiations. The hallmarks of the collaborative process are said to be: full, voluntary and early disclosures of relevant information; acceptance of the parties of the highest level of fiduciary duties towards each other; voluntary acceptance that the aim of the process is to settle the issues and commit to participate fully in the process; transparency of the process; joint retention of neutral expectations; commitment to meeting the legitimate goals of both parties if at all possible; avoidance of litigation or the threat of litigation; disqualification of all legal representatives and experts from participation in any future legal proceedings between the parties outside the collaborative process; and four-way settlement meetings as the principal means by which negotiations and communications can take place. ${ }^{22}$ According to Tesler:

What was unexpected was the degree of creativity that often arises during collaborative negotiations. When the sole agenda is settlement, and when the sole measure of lawyer success is achieving an agreement both clients can accept, and when the lawyers have been instructed by their clients not to include court-based resolution as a part of the range of possible solutions for a given problem, a quantum leap in problem solving frequently occurs: both lawyers and both clients marshal their creative intellects towards finding solutions for each problem that will work well for both parties. There is a concentration of intellectual energy brought to bear solely on solving the problem that is unmatched in any kind of negotiations. ${ }^{23}$

19 Lawrence 'Collaborative Lawyering: A New Development in Conflict Resolution' 2002 Ohio State Journal on Dispute Resolution 432.

20 Spain 'Collaborative Law: A critical reflection on whether a collaborative orientation can be ethically incorporated into the practice of law' 2004 Baylow Law Review 143.

21 Tesler supra 18 at $\mathrm{xx}$.

22 Idem 8.

23 Idem $\mathrm{xx}-\mathrm{xxi}$. 
The training provided to collaborative lawyers allows them to understand the emotive nature of divorces and how one party may use his or her dominance over the other, be it financial or otherwise. As such, collaborative lawyers strive to balance power dynamics and thus create an environment wherein parties can be open to not only hear but, in good faith, attempt to understand the concerns and needs of the other, so as to reach an amicable agreement. ${ }^{24}$ This method enables legal representatives to appreciate the socio-economic realities of their respective clients and to be forward-thinking by allowing parties to reflect on their lives post-divorce and how the decision they take now will affect their lives post-divorce. This allows legal practitioners to not only be concerned about the wellbeing of the clients that instructed them, but to also take the time to assess the needs of the other party to the divorce and create an environment where their clients, when taking particular positions, reflect on how the consequences of such decisions will affect other parties to the divorce. The primary responsibility of the collaborative lawyer is to his or her client and must represent the best interests of such a client. However, in order for the collaborative process to succeed, such practitioner should also caution his or her client to be reasonable on his or her demands and consider the interests of the other party.

While the collaborative process is settlement orientated, it does not disregard emotions generally associated with family law generally, but divorces in particular. The role of collaborative legal practitioners is to adequately advise their clients that emotions generally lead to irrational decisions and that they need to be open minded when negotiating and not necessarily view each other as opponents but partners within a joint solution seeking process. Parties should be encouraged to keep their cool and behave as adults and to not be manipulated by their emotions which might lead to the breakdown of negotiations. Collaborative system allows legal practitioners to move their clients from artificial bargaining positions, motivated by emotions, to the articulation of real needs and interests while assisting them to retain their human decency towards each other and self-respect as they move towards separate lives. ${ }^{25}$ Collaborative lawyers claim that collaborative process allows for family law disputes to be resolved cheaper, faster and fairer than if the parties were to litigate their dispute. ${ }^{26}$ These practitioners believe that collaborative process could result in those who wish to divorce being able to avoid the high costs that are often associated with litigation. ${ }^{27}$ The mere fact that all parties are concerned with the attainment of a workable

24 Mosten Collaborative Divorce Handbook: Helping Families Without Going to Court (2009) 17.

25 Tesler supra 18 at xxi.

26 Fairman supra $\mathrm{n} 8$ at 73

27 Chanen 'Collaborative Counsellors: Newest ADR Option Wins Converts, While Suffering Some Growing Pains' 2000 ABA Journal 52 available from http://www.jstor.org/stable/27845989 (accessed 2016-07-12). 
settlement, that may lead to the negotiation proceedings being more dedicated and focused, enables the parties to reach an agreement faster.

\section{Disqualification Agreement}

A written participation agreement wherein parties bind themselves not to approach the courts during the collaborative process for the resolution of the dispute is the main distinguishing feature of collaborative law. This agreement is so central to the process that should any of the parties decide that the process is not working for him or her and resort to litigation, the legal representatives representing the parties in the process must withdraw, and thus not assist their clients to pursue litigation. ${ }^{28}$ These agreements have also been referred to as limited retention agreements. Such agreements should be thoroughly reviewed and explained to clients, followed by the discussion which adequately explains the collaborative process as well as the scope of attorneys' limited representation in the whole process. Legal representatives, at all times, should receive permission from their respective clients to reveal any information, but should encourage their clients to reveal material information which will lead to the resolution of disputed issues. It has been argued that:

The agreement to participate, or the "disqualification stipulation", gives collaborative law proceedings its spine. This is a document that (1) stipulates the constraints on the lawyer, and consulting professionals' participation. (2) spells out the ethical principles and procedural guidelines for the practice of collaborative law; (3) renders resorting to court a failure (requiring professionals to withdraw); and (4) once understood, voluntarily agreed to, and signed by the participants, gives the teams professional Super Glue to keep the clients from bailing out when the going gets tough. This is a document that defines the "container" for the process and, particularly because it defines the sole goal as collaborative settlement, causes a profound change in mindset and frees the problem solving creativity of the participants. $^{29}$

In a collaborative process, the contractual forswearing of litigation changes everything and creates the correct atmosphere for respectful problem solving. ${ }^{30}$ The fact that there is a formal agreement that collaborative lawyers must withdraw from the case and not participate in litigation, assures that everyone's interests are aligned towards resolution without acrimony. ${ }^{31}$ This agreement can be signed in initial four way meetings between parties and their respective legal

28 Fairman supra $\mathrm{n} 13$ at 239.

29 Schriner 'Agreements to Participate in the Collaborative Law Process' in Gutterman (ed) Collaborative Law: A New Model for Dispute Resolution (2004) 49.

30 Ibid.

31 Ibid 
representatives. This is a distinguishing feature of collaborative law from other alternative dispute resolution methods. ${ }^{32}$ This agreement is referred to as a 'disqualification agreement'. 33 Should negotiations breakdown, the parties will be free to approach other legal practitioners who will assist them to litigate their matter. The confidentiality of the proposals, and discussions generated during the collaborative process, serve to prevent the disclosure and use of information disclosed during negotiations and later litigation. ${ }^{34}$

While collaborative law has grown significantly in various countries, it has nonetheless not escaped criticism. Some lawyers and judges have questioned the 'no court' agreement requiring legal representatives to withdraw should the negotiations fail. They are of the view that parties would incur further and unnecessary costs by bringing new legal representatives on board to assist them to start all over again with litigation and, further, that they would have to start and build a new relationship with such legal representatives during their time of emotional distress. ${ }^{35}$ Doubts have been expressed as to whether the disqualification clauses comply with ethical rules. It has been argued that if ethical rules govern disqualification agreements, these agreements may be unethical because they might place excessive pressure on clients to settle. ${ }^{36}$ It has been argued that collaborative law is unethical more particularly with regard to the 'disqualification agreement' clause because the conflict will materialise every time the collaborative law process is unsuccessful - because the lawyer's obligation to the 'opposing party' will then conflict with the lawyer's duty to 'recommend or carry out an appropriate course of action' (i.e., litigation) for the client. $^{37}$ It has further been observed that potential conflict inevitably interferes with the lawyer's independent professional judgment in considering the alternative of litigation' and forecloses 'a course of action

32 Lande 'The Promise and Perils of Collaborative Law' 2005 Dispute Resolution Magazine 29.

33 Ibid.

34 Voegele, Wray \& Ousky supra n 3 at 1021.

35 Stoner Divorce without Court: A guide to Mediation and Collaborative Divorce (2006) 60.

36 See American Bar Association Ethical Guidelines for Settlement Negotiations (2002) s 3.2.4 available from http://www.abanet.org/litigation/ethics/ settlementnegotiations.pdf (accessed 2014-12-03). In the USA, Rule 1.16(b) of the Model Rules of Professional Conduct permits lawyers to withdraw only under certain conditions, and because clients have unilateral authority to decide whether to accept settlement offers, the Rule does not authorise lawyers to withdraw when clients refuse to follow a lawyers' advice about settlement; the courts have strongly condemned lawyers' withdrawal in these circumstances. Under Rule 1.16(b)(4), a lawyer may withdraw if a "client insists upon taking action that the lawyer considers repugnant or with which the lawyer has a fundamental disagreement', but mere disagreement with a client's decision about settlement generally does not satisfy this condition. See also Lande 'Possibilities for Collaborative Law: Ethics and Practice of Lawyer Disqualification and Process Control in a New Model of Lawyering' 2003 Ohio State Law Journal 1345.

37 Colorado Bar Association (CBA) Ethics Committee released Opinion 1151. 
that "reasonably should be pursued on behalf of the client", or at least considered." 38 It has also been argued that the "disqualification agreement' is unethical because it empowers the one party to terminate the mandate of the other party's legal representative ending the collaborative process. ${ }^{39}$

The fact that both parties would have to withdraw has the potential of allowing one party to impose great legal costs against the other. This might possibly be true when one party has agreed with his or her current legal representative on a certain fee which he or she can afford, and when the process fails, he or she is forced to lose the services of what, to him or her, might be financially reasonable legal representation. Further, that clauses requiring legal representatives to withdraw are not reasonable, more particularly when retaining new counsel imposes extremely asymmetrical costs on the two parties - one party can do it cheaply, the other only at a great expense - then these limited-retention agreements may work serious strategic disadvantage on the costsensitive party ${ }^{40}$ For these reasons, it has been argued that collaborative law seems to be at odds with legal ethics.

It cannot be denied that should disqualification agreements be used to coerce parties to reach settlements, that would be unethical. Nonetheless, these agreements are not intended to force parties to settle. In actual fact, they are used to clarify the very purpose of entering into a collaborative process, which is to reach settlement. These agreements enable parties to be open minded and not to act in a manner that will jeopardise the process. Disqualification agreements enable legal representatives to be constantly focusing on the resolution of the disputes between the parties, which in turn allows the parties to engage meaningfully to resolve their disputes. Opponents of collaborative law have strongly defended the importance and relevancy of disqualification agreements. Lande is of the view that disqualification agreements differ from those traditional withdrawal agreements in that although the structure of the collaborative law process creates a constant risk that the lawyer will withdraw if the client cannot obtain a satisfactory settlement, it is still the client's decision. ${ }^{41}$ Furthermore, if the legal representative is of the view that his or her client is not being truthful to him or her by not

38 Schneyer 'The organized bar and the collaborative law movement: A study in professional change' 2008 Arizona Law Review 296. This argument was made by the Colorado Bar Association. However, the American Bar Association concluded that collaborative practice is not unethical per se, and does not involve an 'unconsentable' conflict and, indeed, creates no lawyer-client conflict.

39 Idem 291.

40 Peppet supra n 16 at 488.

41 Lande supra $\mathrm{n} 32$ at 1352 . Further that lawyers in traditional cases are likely to invoke withdrawal agreements late in the litigation process, often shortly before trial, whereas collaborative processes often occur before litigation begins or early in litigation. Further that lawyers use the traditional withdrawal provision primarily to benefit themselves, whereas collaborative lawyers use the disqualification agreement primarily to benefit the clients 
disclosing everything which needs to be disclosed to assist to reach a settlement and thus threatening the chances of settlement, then such a practitioner should be at liberty to withdraw and terminate the collaboration. ${ }^{42}$

While the American Bar Association conceded that the collaborative lawyer's disqualification agreement creates a contractual 'responsibility' to the other spouse, it nonetheless rejected the view that this 'impair[s] the lawyer's ability to represent his or her client'. ${ }^{43}$ It argued, on the contrary, that the agreement is entirely 'consistent with the client's limited goals for the representation' and poses no risk. ${ }^{44}$ It has been argued that on a practical level, disqualification is a no-brainer. No client heading to litigation after a collaborative case fails would choose their collaborative counsel to represent them in court. The collaborative attorney, who was reasonable and non-positional during the collaborative process, would be the last advocate a client wants in court. ${ }^{45}$ The proponents of collaborative family law argue that the 'disqualification agreement' is intended among others: to enhance the ability of all participants to make the commitment necessary to achieve the best possible outcomes; to create a safe environment so that clients are more likely to identify the best outcomes for their situation; and allows parties to choose their own legal representatives. ${ }^{46}$

What makes collaborative law attractive in the view of the present author is the fact that it is driven by law practitioners who have actually been in practice and, thus, have seen the detrimental effects which litigation can have on the parties involved in family disputes, and more particularly divorces. Collaborative law is not an abstract academic exercise discussed by people who might not have practiced law or had the benefit of consulting with a client who is burning with emotions, due to the anticipated divorce, and who is putting all the blame on the other party for the current state of affairs leading to their divorce. Collaborative law, as an alternative dispute resolution mechanism, is a process advocated for people who have been in such situations and who, through

42 See Schneyer supra $n 38$ at 296.

43 Idem 314.

44 Ibid.

45 Gushurst 'Collaborative Practice: A Paradigm Shift' 2007 The Colorado Lawyer 89.

46 See generally Voegele, Wray \& Ousky supra $n 3$ at 978-982. Further that collaborative law has generated a fair amount of attention regarding legal ethics in use of the model, its unique features, and practice norms. This attention has focused on the ethics of limited representation by attorneys, proper screening of cases appropriate for the model, as well as zealous advocacy within the model, the disqualification of attorney requirement, confidentiality, and use of neutral experts. Despite scrutiny from numerous jurisdictions, no part of the collaborative law model has been found to be unethical. Similarly, there have been no reported incidents of attorneys engaged in unethical practices while practicing collaborative law (Voegele, Wray \& Ousky supra $\mathrm{n} 3$ at 1011). 
experience, have realised that divorces are capable of being resolved amicably.

\section{Should Collaborative Law be practiced in South Africa?}

\section{Alternative Dispute Resolution}

While an in-depth discussion of various Alternative Dispute Resolution (ADR) methods is beyond the scope of this paper, it suffices to mention that ADR in South Africa is understood to:

include dispute resolution processes in which parties have opportunities to make decisions on their rights, interests and remedies and interveners are precluded from making binding determinations for the parties - known variously as facilitation, mediation, conciliation, case appraisal and neutral evaluation. ${ }^{47}$

In the context of family law generally and divorces in particular, the most common ADR method is mediation. In South Africa, mediation has received academic endorsement and there is general consensus that marital issues can be resolved through mediation. ${ }^{48}$ The South African department of Justice and Constitutional Development has also introduced the court-annexed mediation rules which will be implemented in the District and Regional Courts, which rules are said to form part of the Government's concerted effort to transform the civil justice system and are geared at enhancing access to justice. ${ }^{49}$ While an in-depth discussion of mediation is beyond the scope of this paper, and

47 Boulle 'Promoting Rights Through Court-Based ADR?' 2012 SAJHR 3.

48 See generally Boniface 'A humanistic approach to divorce and family mediation in the South African context: a comparative study of Westernstyle mediation and African humanistic mediation' 2012 African Journal on Conflict Resolution 101; Goldberg 'Family mediation is alive and well in the United States of America: a survey of recent trends and developments' 1996 TSAR 370' De Jong 'A pragmatic look at mediation as an alternative to divorce litigation' 2010 TSAR 515; De Jong 'Giving children a voice in family separation issues : a case for mediation: aantekeninge' 2008 TSAR 785; De Jong 'The need for new legislation and/or divorce mediation to counter some commonly experienced problems with the division of assets upon divorce' 2012 Stell LR 225; and De Jong 'Divorce mediation in Australia valuable lessons for family law reform in South Africa' 2007 Comparative and International Law Journal of Southern Africa 280.

49 Court-annexed mediation available from http://www.conflict dynamics.co.za/SiteFiles/222/DOJ\%20Mediation \% 20Rules \% 20Booklet.pdf (accessed 2012-12-04). 
the fact that mediation has been addressed elsewhere, it is nonetheless fitting to properly compare mediation with collaborative law. ${ }^{50}$

\section{Mediation v Collaborative Law}

Both mediation and collaborative law endeavours to assist the parties to negotiate their differences in a more welcoming environment than what they may be exposed to if they were engaged in litigation. Both processes are intended at keeping parties away from court by creating a suitable environment wherein they can resolve their disputes. Parties' communication is vastly improved due to their active involvement in both processes and can, themselves, make important decisions regarding their divorce.

There are recognisable differences between mediation and collaborative law. In mediation, there is a neutral figure who oversees the process, whereas in collaborative law, each party brings his or her legal representative to assist him or her to negotiate. This means that mediation, in the context of divorce, can, and usually is, a three way process, whereas collaborative law is a four way process. This simply entails that in mediation there is a third party who is supposed to be impartial and neutral whose role is to facilitate the negotiations between the parties thereby assisting them to reach an amicable settlement that recognises the needs and rights of all family members. ${ }^{51}$ Whilst in collaborative law, there is no neutral person in the strict sense of the word, and both parties bring their own legal representatives who should assist them to reach settlement.

Another distinguishing feature between the two processes is the fact that with regards to collaborative law, both legal representatives sign an agreement which binds them to withdraw and, thus, cease to represent their clients should the parties fail to reach settlement. In that case, such legal representatives cannot assist the parties to litigate against each other should they wish to do so. Alternatively, there is no such formal commitment to the resolution of the disputes between the parties from the mediator as far as mediation is concerned. In mediation, parties may candidly disclose any facts or information, even if it is of a highly personal nature, without being afraid that any statements or concessions made in the mediation process could later be used against them in litigation that might follow an unsuccessful mediation attempt. ${ }^{52}$ Parties involved in collaborative law are actively encouraged to disclose all

50 See O'Leary Mediation in Family \& Divorce Disputes (2014); Boniface 'African-style Mediation and Western-style Divorce and Family Mediation: Reflections for the South African context' 2012 PER 377; and see also De Jong 'An acceptable, applicable and accessible family-law system for South Africa - some suggestions concerning a family court and family mediation' 2005 TSAR 33.

51 De Jong 2010 TSAR supra n 48 at 515.

52 Dewdney 'The partial loss of voluntariness and confidentiality in mediation' 2009 Australasian Dispute Resolution Journal 18; 
relevant information honestly and in good faith in order to assist the process.

However, it should be noted that the process of mediation allows parties ample scope to engage in a structured discussion to negotiate issues in dispute relating to their divorce, which might include, inter alia, the division of assets, care and contact with children, and maintenance. ${ }^{53}$ Such a process is driven by a person who should be viewed as impartial and who does not have an interest in the matter, other than assisting the parties by creating an environment where the parties can endeavour to resolve their marital issues. Family law mediation as an alternative to litigation has also received judicial approval in South Africa. ${ }^{54}$ Brassey AJ in $M B v N B^{55}$ held that:

Mediation can produce remarkable results in the most unpropitious of circumstances, especially when conducted by one of the several hundred people in this country who have been trained in the process. The success of the process lies in its very nature. Unlike settlement negotiations between legal advisers, in themselves frequently fruitful, the process is conducted by an independent expert who can, under conditions of the strictest confidentiality, isolate underlying interests, use the information to identify common ground and, by drawing on his or her own legal and other knowledge, sensitively encourage an evaluation of the prospects of success in the litigation and an appreciation of the costs and practical consequences of continued litigation, particularly if the case is a loser. ${ }^{56}$

There are those who have argued that mediation, in general, is an inherently collaborative process. ${ }^{57}$ Although mediation has sometimes been labelled as such, collaborative law is functionally different from

53 De Jong 2012 Stell L $R$ supra $\mathrm{n} 48$ at 235.

54 See among others MB v NB supra n 1, S v J (695/10) [2010] ZASCA 139 (19 November 2010), Van den Berg $v$ Le Roux [2003] 3 All SA 599 (NC), Townsend-Turner and another $v$ Morrow [2004] 1 All SA 235 (C), Gv G 2003 (5) SA 396 (Z).

$55 M B \vee N B$ supra $n 1$ par 23.

56 Idem par 50. Brassey AJ stated further that 'I am given to understand that in England the all but obligatory recourse to mediation has profoundly improved the process of dispute resolution. Parties resolve their problems so much more cheaply as a result and the burden on the court rolls has been considerably lightened. Informed estimates put the success rate of mediation at between eighty and ninety percent. For present purposes it is unnecessary, indeed undesirable, for me to say more about the general imperatives that favour mediation as a means of settling cases. I do not even feel the need to say much more about the need for mediation in family disputes. But I can say with confidence that the parties would have been well served if they had submitted this dispute to mediation and then fought out, if fight they must, the one or two issues of fundamental concern to them'

57 Ackerman 'Disputing Together: Conflict Resolution and the Search for Community' 2002 Oido State Journal on Dispute Resolution 71. Ackerman argues that "the collaborative nature of mediation suggests a "friendlier" process, that the ideal circumstances, should promote an atmosphere more conducive to community building than the adversarial, "winner takes all" nature of adjudicative process'. 
mediation in many ways. ${ }^{58}$ It has been argued that the standard process of a collaborative divorce involves many steps, which include: making first contact with client and attorney; first communications with the other party or opposing counsel; pre-meetings, agenda-setting, and the first four-way meeting (of the parties and their attorneys); the debriefing (where the parties and their attorneys talk about the first four-way meeting); the mid-game (involving a number of four-way meetings); and the end-game (usually concluding the settlement). ${ }^{59}$

\section{Collaborative Law in South Africa}

The debate regarding the adoption of collaborative law in South Africa would be enriched by dealing with important questions regarding the value of this form of dispute resolution method. Given the fact that South Africa has adopted an extensive mediation driven approach towards family law dispute resolution, does collaborative law have a place in South Africa? Can collaborative law be an alternative not only to litigation but to mediation itself? Would South African family lawyers buy into a form of dispute resolution which totally discourages litigation? Would collaborative law lead to divorce potential litigants reaching settlement before litigation? What value would collaborative practice bring to the South African family law jurisprudence generally, and the divorce regime in particular? Perhaps all these questions could be effectively answered only if family law practitioners in South Africa consciously decide to start practising collaborative law. Nonetheless, the present author is of the view that collaborative law, just like any other method of ADR, does have a place to play in South Africa. As such, if potential litigants wish to utilise collaborative law, there must be practitioners who are willing to participate in it. Collaborative law enables legal representatives not to think about themselves by pushing for an outcome which will lead to their clients emerging as victorious and them being viewed as better legal representatives. This winning mentality is part of the South African divorce litigation system which becomes more evident when legal representatives attempt to reach a settlement in what is referred to as round table conferences in South Africa. These meetings are often attended by parties together with their legal representatives. It is at these meetings where the litigious mentality of South African divorce legal practitioners clearly comes out - where practitioners will be arguing firmly and, thus, advocating for the demands of their clients. Even though settlement agreements, at times, are reached by the parties, such agreements (due to the skill and experience of legal practitioners) often result in the prejudice of one of the parties who might have been made to compromise on issues that he or she should not have had to, only to realise, post-divorce, that he or she got a raw deal. Collaborative law can address this and ensure that practitioners are more open minded when

58 Beyer 'Pragmatic look at Mediation and Collaborative law as Alternatives to Family law Litigation' 2008 St Mary's Law Journal 320.

59 Ibid; Tesler supra n 18 at 102. 
advising and representing their clients by pushing for a more equitable outcome for both parties.

South African family law practitioners, who see value in participating in this process, would be required to encourage their clients to engage meaningfully in a joint problem solving initiative as opposed to the traditional adversarial system. Legal practitioners who embrace the collaborative process would have to be genuine in their attempt to resolve conflicts between their respective clients and must act in good faith. Round table conferences are suitable platforms to practice collaborative law. Even though these round table conferences, at times, are convened to express the position of parties and, therefore, often lead to no settlement at all, the present author is of the view that these forums can be a good start to introducing collaborative law in South Africa. ${ }^{60}$ Perhaps it is through these round tables where legal representatives could look beyond the emotions and tensions of their respective clients and create an environment wherein parties can be directly involved in the negotiations. This can be achieved if and when legal representatives do not necessarily see themselves as opponents but as role players in a collaborative effort which is intended to assist clients to settle their disputes. It cannot be disputed that an early settlement is particularly important in the context of divorce in order to prevent unnecessary costs which may occur if the parties are unable to agree on the most important aspects of their divorce - creating a litigious environment leaving the matter to be decided by the court and, thus, resulting in a winner and a loser between the parties. Divorce courts appreciate the parties' efforts to resolve issues between themselves and to come to court only to request the court to make their collective decision an order of court. In most instances, if the settlement is sound the court will rubber stamp it. However, the court retains its discretion to reject the settlement if it is grossly unfair to one of the parties. It has been held that:

It has always been the trend in divorce proceedings, more so than in other civil actions, for parties to elect to resolve their disputes in a non-adjudicatory manner. Through the use of dispute resolution mechanisms designed to foster the amicable settlement of disputes, such as conciliation or mediation, parties arrive at a negotiated settlement of the issues raised in an action for the dissolution of their marriage relationship. The usual outcome of such a negotiated settlement is the conclusion of an agreement, for the terms of the settlement to be recorded in a written document, and for it to be made an order of the court. The record of this agreement or contract is commonly referred to as a settlement agreement, a deed of settlement or a consent paper. The agreement usually deals with matters such as the division of the assets of the parties, the payment of maintenance, custody of, and contact with the children, and the payment of the costs of the proceedings. ${ }^{61}$

60 As practicing attorney, I conduct at least four round tables in a month.

61 Ex parte Le Grange and Another; Le Grange $v$ Le Grange 2013 (6) SA 28 (ECG) par 1. See also section 7(1) of the Divorce Act 70 of 1979, which provides that 'a court granting a decree of divorce may in accordance with a written 
This author is of the view that family law practitioners should commit to transform roundtable conferences into collaborative law forums which will create an environment for parties to thoroughly and honestly discuss issues such as finances, properties, parental responsibilities and rights over children and the manner of their divorce. It cannot be disputed that the current South African adversarial court system has proved to be unsuitable for family law disputes. It fails to provide a contextual and close assessment of the parties' particular needs and does not cater to the post-divorce needs of litigants. Often, a magistrate or judge will make an order based on the facts presented by the legal representatives to him or her and, based on this, determine who the winner of the case is. This system does not go beyond understanding what life post-divorce is likely to be like for the parties before the court. As such, in order to understand the real issues affecting parties, there needs to be a forum where such issues can be canvassed in an open and honest manner. The present author believes that collaborative law is that alternative. This is because once the parties, together with their legal representatives, have addressed all the issues and reached settlement, the settlement can be taken to court to be made an order of court.

Collaborative law also makes provision for other people, with expertise in areas such as child related issues and finances, to be part of the process in order to assist parties to explore interests rather than positions and, therefore, make decisions which will benefit them postdivorce. The legal representatives will facilitate the process to ensure that parties negotiate in a manner that will bring about progress in the process. It is argued that progress will be brought about when practitioners sign a clear and well drafted 'participation agreement' wherein they would declare and commit themselves to withdrawing from the process should the negotiations breakdown and the parties fail to reach agreement - and therefore not participate in the litigation should either of the parties wish to litigate the matter.

\section{Conclusion}

Over the years, litigation has been used to resolve family disputes. However, in recent years there has been a deliberate effort to encourage people to resolve their family disputes using ADR mechanisms. While various ADR methods are available, this paper discussed collaborative law as an option which can be used to resolve divorce disputes. It has been argued that collaborative law should be formally introduced in South Africa because it is best suited to deal with issues surrounding divorces. In order for collaborative law to succeed in South Africa, ongoing training should be provided to all those practitioners who are willing to practice it. The success of collaborative law practice in the USA

agreement between the parties make an order with regard to the division of the assets of the parties or the payment of maintenance by the one party to the other'. 
and Canada came as a result of those who started this process and those who provided training and support to those who were willing to receive such training. ${ }^{62}$ There mere fact that there are law firms in the USA and Canada which have established specialised units to deal specifically with collaborative law, means that South Africa can draw lessons from these countries on how to carry out collaborative law practice. Perhaps more research needs to be conducted on how South Africa can incorporate this practice of dispute resolution within its borders.

62 Fairman supran 13 at 240. Fairman reiterates that 'Stu Webb, is credited as the first to articulate the concept and put it into practice around 1990. Since then, thousands of lawyers have been trained in the collaborative law model; tens of thousands of cases have been resolved with it in the United States and Canada. Collaborative law practice groups exist in virtually every state in the nation. Indeed, major law firms are even hiring partners to head up their collaborative law sections'. 